\title{
Comparing nitrogen management on dairy farms - Canterbury case studies
}

\author{
J.B. PINXTERHUIS and J.P. EDWARDS \\ DairyNZ Ltd, PO Box 85066, Lincoln University, Lincoln 7647, New Zealand
}

Ina.Pinxterhuis@dairynz.co.nz

\begin{abstract}
Five Canterbury dairy farmers participate in the Forages for Reduced Nitrate Leaching programme (FRNL) to co-develop options for less environmental impact. Farm practices were adapted and new mitigation options were implemented. To assess farm environmental performance, the Overseer model was used to estimate nitrogen $(\mathrm{N})$ leaching, $\mathrm{N}$ surplus and $\mathrm{N}$ conversion efficiency (NCE) for each farm and each year. When discussing the results with farmers, it appeared that these indicators for environmental performance are limited when comparing farm management strategies. The Overseer estimates include $\mathrm{N}$ fixation, which is influenced by model assumptions, and $\mathrm{N}$ leaching, estimates that strongly depend on soil type and climate entered into the model. To enable better comparisons between farms and years, a simplified $\mathrm{N}$ surplus and NCE were calculated using farmer recorded $\mathrm{N}$ inputs and $\mathrm{N}$ outputs, i.e. fertiliser, imported supplement, production and exported supplements. Effects of improved management and new mitigation options are presented. Four of the farms improved their $\mathrm{N}$ surplus and NCE and three reduced their Overseer-estimated N leaching over 3 years $(2014,2015$ and 2016).
\end{abstract}

Keywords: nitrogen, surplus, conversion efficiency, dairy systems, nitrate leaching, environmental performance

\section{Introduction}

Intensification of agricultural land has been linked to the degrading of water quality in New Zealand (Larned et al. 2004) and has resulted in the recent development of central and local government regulation, as well as strong responses from the agricultural sector. Both regulation and industry responses have focussed on controlling contaminant losses, rather than controlling inputs, so that farmers have flexibility to find innovative, research-driven solutions. Regionally, limits are set to nitrogen $(\mathrm{N})$ loss to water $(\mathrm{N}$ leaching hereafter, the main component for dairy farms). Farm Environment Plans support uptake of good management practice. Enforcing limits requires practical and affordable monitoring plans. The expense and challenges of measuring the impact of land use on water quality means regional councils require a tool to estimate nutrient losses. In New Zealand the tool of choice is the nutrient budgeting model OVERSEER ${ }^{\circledR}$ (referred to as Overseer hereafter; Watkins \& Selbie 2015).

$\mathrm{N}$ leaching from land use varies widely depending on soil type and climate, and Overseer reflects these differences. Efforts to determine representative farm systems, soils and climates to develop meaningful benchmarks for $\mathrm{N}$ leaching have been unsuccessful to date (Pinxterhuis et al. 2015b). Furthermore, mitigation options being explored in research programmes such as Forages for Reduced Nitrate Leaching (FRNL) and Pastoral 21 (P21) target the efficiency with which nutrients are used in the farm system. The impact of these options on $\mathrm{N}$ leaching is not necessarily reflected in Overseer, which uses assumptions and generalisations (Watkins \& Selbie 2015). These factors make it difficult for farmers to benchmark and compare the efficiency of their farming practices using $\mathrm{N}$ leaching values only.

The Overseer model output presents important information, other than $\mathrm{N}$ leaching, which can be used for benchmarking and comparing farm performance, including $\mathrm{N}$ surplus (the difference between $\mathrm{N}$ inputs and $\mathrm{N}$ outputs; $\mathrm{kg} \mathrm{N} /$ ha/year) and $\mathrm{N}$ conversion efficiency (NCE, the ratio of $\mathrm{N}$ outputs/ $\mathrm{N}$ inputs, \%). The main $\mathrm{N}$ inputs in pasture-based New Zealand systems are purchased fertilisers, feed and biological $\mathrm{N}$ fixation by legumes. Nitrogen outputs are all crop and animal products exported off-farm. A high NCE and a low $\mathrm{N}$ surplus combine maximal productivity with minimal environmental $\mathrm{N}$ loss (De Klein et al. 2017). $\mathrm{N}$ surplus is an indicator of the potential impact on the local environment. Soil type, climate, and factors influencing gaseous losses control how much of the $\mathrm{N}$ surplus eventually leaches below the root zone, e.g. the same $\mathrm{N}$ surplus results in higher leaching from soils with low Profile Available Water (PAW) than from soils with higher PAW, and the same $\mathrm{N}$ surplus results in higher leaching from arable land than from grasslands (Schröder \& Neeteson 2008).

Here, data collected from five dairy monitor farms in the FRNL programme are used to demonstrate how to compare farm performance using Overseer output and a simplified N surplus and NCE that include only information that farmers can easily record. While Overseer reports environmental impact, it is suggested that the simplified method engages farmers better with indicators of management performance to which they can relate and influence. 


\section{Methods}

The FRNL monitor farm network was established in the 2014/2015 season, as part of the FRNL programme. FRNL investigates options to reduce $\mathrm{N}$ leaching through reduced animal $\mathrm{N}$ intake, urinary $\mathrm{N}$ concentration, and improved plant $\mathrm{N}$ uptake by using mixed-species pasture, low-N forage crops and catch crops. In Canterbury, the network has nine farms: four dairy farms, a mixed arable-dairy farm, two arable farms and two mixed livestock farms. This paper presents data from the milking platforms of four dairy farms and the mixed arable-dairy farm, located from North to South Canterbury: near Culverden, Oxford, Dunsandel, Ruapuna and St Andrews (see www.dairynz.co.nz/frnl for a map and further information). Detailed data were recorded by the individual farmers, such as type and amount of supplement fed and when it was fed, timing and amount of fertiliser, effluent and irrigation applied/ paddock, and stock movements. A comprehensive data collection spreadsheet was developed and a researcher visited the farms monthly to ensure data recording was complete and accurate. Data from the first season (2014/2015) were used to set up Farmax and Overseer models; alternative scenarios were developed with the farmers and modelled. Farmax models the effects of farm system changes on production and economic variables (Bryant et al. 2010). Results were presented to the farmers in sufficient time to make management changes for the second season (2015/2016). The intention of this exercise was to increase the efficiency of the farms before adopting new practices as part of FRNL, and for the monitor farmers to become familiar with the modelling process and interpreting results. It was during this process that the farmers concluded $\mathrm{N}$ leaching numbers from Overseer alone were not sufficient to compare and assess environmental performance of their farms and management.

A similar process was used at the start of the third (2016/2017) season, but using the DairyNZ Whole Farm Model to enable modelling of the FRNL options of plantain, fodder beet and catch crops. Some of the modelling results have been presented elsewhere (Beukes et al. 2017; Pinxterhuis et al. 2017; Beukes et al. 2018). Following this feedback, most of the farmers adopted some of or all the mitigation options (Table 1). Monitoring continued to assess the impact of these changes on farm performance.

The detailed data were used to prepare Overseer nutrient reports at the end of each season. This paper reports two versions of $\mathrm{N}$ surplus and NCE: the Overseer estimates, which include irrigation, rain and biological $\mathrm{N}$ fixation, and a simplified calculation that only includes the fertiliser and supplement inputs and products sold off-farm, i.e. a surplus or efficiency of purchased N (Hansen et al. 2016).

\section{Results}

Descriptions of the changes made by each of the farmers are given in Table 1, and key performance indicators for the farm systems are given in Table 2 (all data are

Table 1 Changes implemented by FRNL dairy monitor farmers. MP = milking platform; SB = support block. Unless stated otherwise, fodder beet on the MP was used for low- $\mathrm{N}$ feed in autumn and transitioning cows onto the crop in preparation for winter grazing, and plantain was established in mixed-species pasture as part of the regular pasture renewal.

\begin{tabular}{|c|c|c|}
\hline Farm & Changes made in 2015/2016 from 2014/2015 & Changes made in $2016 / 2017$ from $2015 / 2016$ \\
\hline A & $\begin{array}{l}\text { More imported supplement, but less grain used. } \\
\text { Similar amount of } \mathrm{N} \text { fertiliser. Continued to lift } \\
\text { fodder beet from SB to feed on MP in autumn } \\
\text { and spring. }\end{array}$ & $\begin{array}{l}\text { More N fertiliser and imported supplement. Continued to lift fodder beet } \\
\text { from SB and feed on MP in spring and autumn; used maize silage. }\end{array}$ \\
\hline $\mathrm{B}$ & $\begin{array}{l}\text { Similar amount of } \mathrm{N} \text { fertiliser. Less imported } \\
\text { supplement. Lifted fodder beet from SB to feed } \\
\text { on newly constructed feed pad on MP. }\end{array}$ & $\begin{array}{l}\text { Less } \mathrm{N} \text { fertiliser. More low-N imported supplement. Grew } 12 \text { ha of } \\
\text { fodder beet on MP. Established plantain on } 25 \text { ha ( } 7 \% \text { of MP). }\end{array}$ \\
\hline $\mathrm{C}$ & $\begin{array}{l}\text { Less } \mathrm{N} \text { fertiliser and imported supplement. } \\
\text { Lower stocking rate accordingly. Grew } 8.5 \text { ha } \\
\text { of fodder beet on MP. }\end{array}$ & $\begin{array}{l}\text { More fertiliser and imported supplement. Grew } 8.5 \text { ha of fodder beet } \\
\text { on MP. Followed fodder beet with catch crop of oats and Italian rye } \\
\text { grass. Established plantain on } 17 \text { ha ( } 5 \% \text { of MP), and on } 60 \text { ha under } \\
\text { sown into existing pastures ( } 16 \% \text { of MP). }\end{array}$ \\
\hline $\mathrm{D}$ & $\begin{array}{l}\text { No change in } \mathrm{N} \text { fertiliser. Less imported } \\
\text { supplement. Established plantain on } 21 \text { ha } \\
(6 \% \text { of MP). }\end{array}$ & $\begin{array}{l}\text { Similar amount of } \mathrm{N} \text { fertiliser and imported supplement. Established } \\
\text { plantain on an additional } 16 \text { ha ( } 4 \% \text { of MP). Grew } 14 \text { ha of fodder beet } \\
\text { on MP. Followed the fodder beet with a catch crop of oats. }\end{array}$ \\
\hline $\mathrm{E}$ & $\begin{array}{l}\text { Similar amount of } \mathrm{N} \text { fertiliser. Less imported } \\
\text { supplement. Lower stocking rate, allowing } \\
\text { establishment of plantain on } 70 \text { ha ( } 22 \% \text { of MP). } \\
\text { Already included plantain in pasture seed mix } \\
\text { before start of FRNL. }\end{array}$ & $\begin{array}{l}\text { No change in N fertiliser. Less imported supplement. Grew } 6 \text { ha of } \\
\text { fodder beet on MP, followed by catch crop of oats and Italian ryegrass. } \\
\text { Established plantain on an additional } 22 \text { ha. Ran replacement animals } \\
\text { on MP to control surplus pasture for parts of October, December, } \\
\text { January and March. }\end{array}$ \\
\hline
\end{tabular}




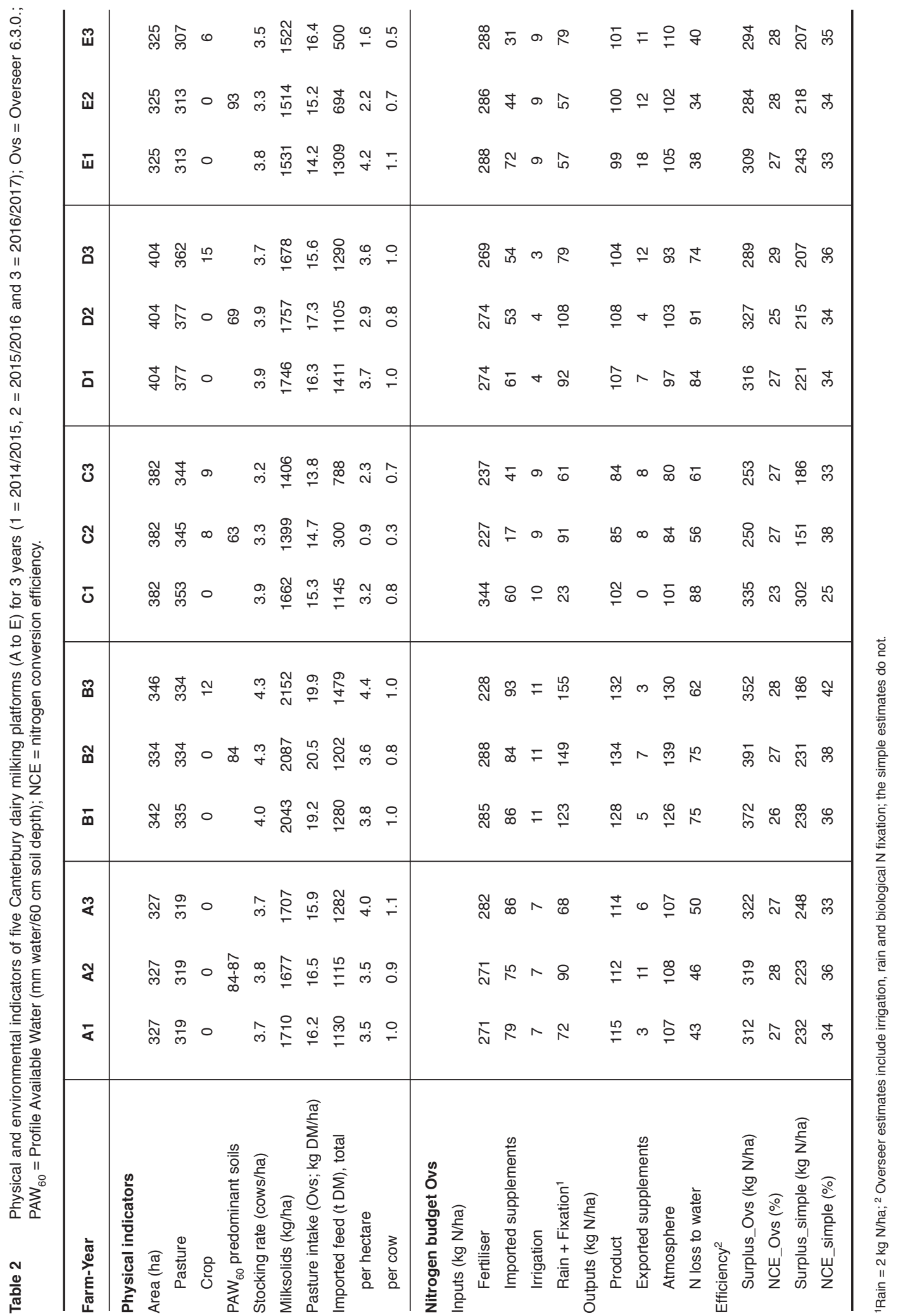




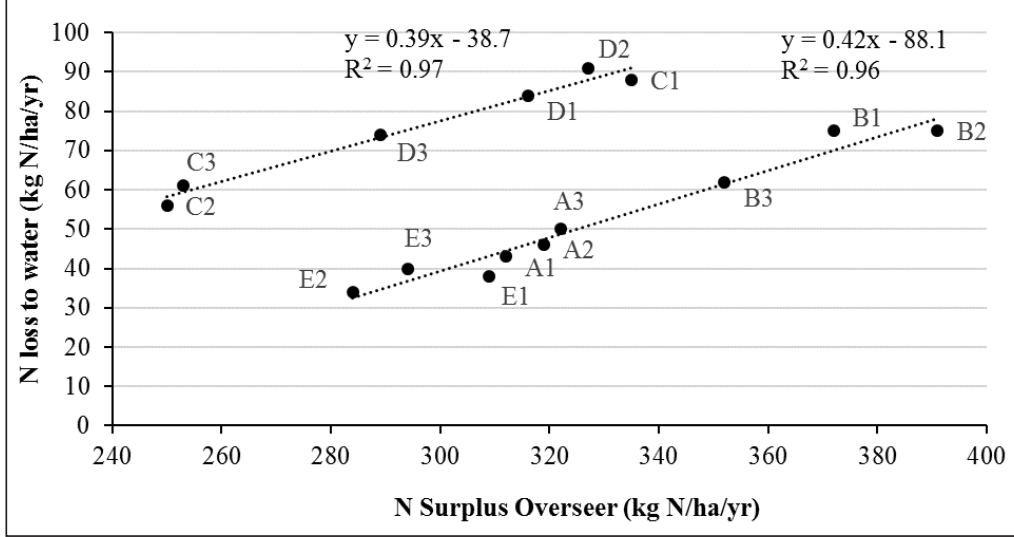

Figure 1 Nitrogen $(\mathrm{N})$ loss to water (predominantly $\mathrm{N}$ leaching) from five Canterbury dairy farms ( $\mathrm{A}$ to $\mathrm{E}$ ) in relation to farm $\mathrm{N}$ surplus. Both parameters as estimated by Overseer 6.3.0. Three data points are given/farm: (1) 2014/2015, (2) 2015/2016, and (3) $2016 / 2017$. Farm N surplus = (fertiliser + supplement + irrigation + biological $\mathrm{N}$ fixation + rainfall) - (animal and plant products). Equations and $\mathrm{R} 2$ for linear regressions are given for farms on extremely light soils (top line) and farms on light soils (bottom line).

regressions shown in Figure 1. It is highly unlikely this could be achieved by using a lower $\mathrm{N}$ input while maintaining production and current farm systems: an NCE of $60-80 \%$ would be required, well above that achieved by experimental farms (Pinxterhuis et al. 2015a). Therefore, other options are needed and have been explored in modelling studies.

Modelling implementation of known $\mathrm{N}$ leaching mitigation options, such as variable rate irrigation across the farm, early culling and drying-off cows to reduce pasture DM intake/ha in autumn, and reducing $\mathrm{N}$

on an annual basis). Estimates of $\mathrm{N}$ leaching during the 'base' 2014/2015 season varied widely between farms ( 28 to $88 \mathrm{~kg} \mathrm{~N} / \mathrm{ha}$ ). Three farms reduced their $\mathrm{N}$ leaching in the course of the 3 years studied; the other two had small increases in leaching. N surplus and NCE improved on four farms.

$\mathrm{N}$ leaching comprised a greater proportion of the $\mathrm{N}$ surplus for Farm C and Farm D (PAW ${ }_{60} 50-80 \mathrm{~mm}$; extremely light free-draining soil types) compared with the farms on the light soils ( $\mathrm{PAW}_{60} 80-110 \mathrm{~mm}$ ). This is illustrated in Figure 1. This Figure also illustrates the relationship between $\mathrm{N}$ surplus and $\mathrm{N}$ leaching.

\section{Discussion}

Compared with earlier data from Waikato farms (Beukes et al. 2012) and the high eco-efficient experimental farm of Pastoral 21 in Canterbury (Pinxterhuis et al. 2015a), the FRNL monitor farms had a high N surplus and low NCE. This was due to their high N fertiliser and supplement use (average $274 \mathrm{~kg} \mathrm{~N} / \mathrm{ha}$ and $3.2 \mathrm{t}$ $\mathrm{DM} /$ ha, respectively) compared with the Waikato farms (average of $121 \mathrm{~kg} \mathrm{~N} / \mathrm{ha}$ and $1.3 \mathrm{t} \mathrm{DM} / \mathrm{ha}$, respectively) and the Canterbury experimental farm $(179 \mathrm{~kg} \mathrm{~N} /$ ha and $1 \mathrm{t} \mathrm{DM} / \mathrm{ha}$, respectively), and the associated diminishing return from these relatively high $\mathrm{N}$ inputs (Whitehead 1995).

Regulation requires dairy farms in some Canterbury catchments to reduce $\mathrm{N}$ leaching by $30-35 \%$ from their baseline (average leaching from 2009-2013). To achieve a 35\% reduction from their 2014/2015 level, a reduction in N surplus by $24-26 \%$ would be required for the monitor farms on low $\mathrm{PAW}_{60}$ soils and 12$14 \%$ for the farms on higher $\mathrm{PAW}_{60}$ soils, using the inputs with an associated reduction in stocking rate, resulted in a $30 \%$ reduction in $\mathrm{N}$ leaching for Farm B, but also reduced production and profit (Pinxterhuis et al. 2017, using Overseer 6.2.3). Modelling of options researched in FRNL (mixed-species pastures with plantain, fodder beet and catch crops) reduced $\mathrm{N}$ leaching from Farm B by nearly $20 \%$ while increasing production and profit by 2 and $10 \%$, respectively (Beukes et al. 2017, using the Whole Farm Model). Including plantain in pasture reduced urinary $\mathrm{N}$ concentration and $\mathrm{N}$ leaching from urine patches (Carlton et al. 2017; Woods 2017). Fodder beet is a low-N feed with reduced urinary $\mathrm{N}$ excretion (Waghorn et al. 2018) and catch crops utilise water and soil mineral $\mathrm{N}$ in cooler seasons of the year, thereby reducing the risk of $\mathrm{N}$ leaching (Malcolm et al. 2016).

Default values for utilisation, $\mathrm{N}$ content and metabolisable energy (ME) of pasture and supplementary feed were used to estimate $\mathrm{N}$ leaching, $\mathrm{N}$ surplus and NCE, in accordance with Overseer best practice data input standards for the model (www. overseer.org.nz). Overseer's calculations of pasture intake use these values, as well as amount of imported supplement and energy requirements for the achieved animal production. Consequently, when farms improve utilisation and quality of pasture and supplement offered, leading to better feed conversion to milksolids production, Overseer will assume increased pasture intake and associated biological $\mathrm{N}$ fixation and animal $\mathrm{N}$ excretion. This increases Overseer's estimated $\mathrm{N}$ surplus (by increasing $\mathrm{N}$ fixation) and $\mathrm{N}$ leaching (by increased animal $\mathrm{N}$ excretion). For example, Farm B consistently achieved high estimated pasture intake 
compared with the other farms; this was associated with high $\mathrm{N}$ fixation, high $\mathrm{N}$ surplus (Overseer) and relatively high $\mathrm{N}$ leaching compared with the other farms on higher PAW 60 soils (Figure 1). However, the simple $\mathrm{N}$ surplus was on a par with that of the other farms, and relatively low in the third year. The simple $\mathrm{N}$ surplus only includes parameters that the farmer can control directly and can also access without a model: fertiliser, imported supplement, production and exported supplement. Assumptions for $\mathrm{N}$ content of supplement and product may be used, but values do not change with updates of the Overseer model and can be compared between farms across different soils and climates.

An additional benefit of the simple $\mathrm{N}$ surplus is that it may show the effect of new mitigation options before Overseer has been able to incorporate these options in the model. Mitigations such as plantain, low-N feeds and catch crops all work by increasing the efficiency with which $\mathrm{N}$ is used within the system. Indeed, the four farms that implemented these options improved their NCE. However, if the N surplus does not change, the same amount of $\mathrm{N}$ may be at risk of loss to the environment.

The results of the present study demonstrate Overseer's estimated $\mathrm{N}$ leaching is not suitable to compare the efficiency of different farm systems and management practices, because of the effects of soil type, climate and model assumptions. When more years of data are available for the monitor farmers, actual pasture and supplementary feed quality will be used in the model, to make full use of its capability. The simple $\mathrm{N}$ surplus is more likely to increase awareness of potential environmental impact and ultimately lead to practice change because it is easier to interpret. Using the simple $\mathrm{N}$ surplus, however, does not decrease the need for models such as Overseer. It is still necessary to estimate $\mathrm{N}$ leaching to reconcile farm practice with water quality at the catchment level, e.g. for developing regulation to maintain or achieve acceptable water quality.

\section{ACKNOWLEDGEMENTS}

Research was completed as part of the Forages for Reduced Nitrate Leaching programme with principal funding from the New Zealand Ministry of Business, Innovation and Employment. The programme is a partnership between DairyNZ, AgResearch, Plant \& Food Research, Lincoln University, Foundation for Arable Research and Landcare Research.

We whole-heartedly thank the monitor farmers for their involvement in the programme, their continued efforts to collect the required data for our research and their interest in improving the environmental impact of their farming business.

\section{REFERENCES}

Beukes, P.C.; Chikazhe, T.; Edwards, J.P. 2018. Exploring options for cross-sectoral collaboration to reduce nitrogen leaching while maintaining profitability: A Canterbury case study. Journal of New Zealand Grasslands 80: 191-194.

Beukes, P.C.; Edwards, P.; Coltman, T. 2017. Modelling options to increase milk production while reducing $\mathrm{N}$ leaching for an irrigated dairy farm in Canterbury. Journal of New Zealand Grasslands 79: 139-146.

Beukes, P.C.; Scarsbrook, M.R.; Gregorini, P.; Romera, A.J.; Clark, D.A.; Catto, W. 2012. The relationship between milk production and farm-gate nitrogen surplus for the Waikato region, New Zealand. Journal of Environmental Management 93: 44-51.

Hansen, S.; Koesling, M.; Schüler, M.; Fystro, G.; Bleken, M.A. 2016. Large variation in nitrogen efficiency among organic and non-organic dairy farms. In: Proceedings of 19th Nitrogen Workshop: efficient use of different sources of nitrogen in agriculture from theory to practice: 82-83. 27th-29th June 2016, Skara, Sweden. Accessed 4th August 2018. http:// akkonferens.slu.se/nitrogenworkshop/wp-content/ uploads/sites/18/2014/05/Nitrogen-Absracts-USB ny.pdf.

Bryant, J.R.; Ogle, G.; Marshall, P.R.; Glassey, C.B.; Lancaster, J.A.S.; Garcia, S.C.; Holmes, C.W. 2010. Description and evaluation of the Farmax Dairy Pro decision support model. New Zealand Journal of Agricultural Research 53: 13-28.

Carlton, A.J.; Cameron, K.C.; Edwards, G.R.; Di, H.J.; Clough, T.J. 2017. Nitrate leaching losses are lower from diverse forages containing plantain than from standard ryegrass and white clover forages under different irrigation types. New Zealand Journal of Agricultural Research 61: 1-14.

De Klein, C.A.M.; Monaghan, R.M.; Alfaro, M.; Gourley, C.J.P.; Oenema, O.; Mark Powell, J. 2017. Nitrogen performance indicators for dairy production systems. Soil Research 55: 479-488.

Larned, S.T.; Scarsbrook, M.R.; Snelder, T.H.; Norton, N.J.; Biggs, B.J.F. 2004. Water quality in lowelevation streams and rivers of New Zealand: recent state and trends in contrasting land-cover classes. New Zealand Journal of Marine and Freshwater Research 38: 347-366.

Malcolm, B.; Teixeira, E.; Johnstone, P.; Maley, S.; De Ruiter, J.; Chakwizira, E. 2016. Catch-crops after winter grazing for production and environmental benefits. Agronomy New Zealand 46: 99-108.

Pinxterhuis, J.B.; Beare, M.H.; Edwards, G.R.; Collins, R.P.; Dillon, P.; Oenema, J. 2015a. Ecoefficient pasture based dairy farm systems: a comparison of New Zealand, The Netherlands and Ireland. Grasslands Science in Europe 20: 349-366. 
Accessed: 15th August 2018. http://www.nvwv. $\mathrm{nl} /$ sites/default/files/files/egf2015-Pinxterhuis $\% 20$ -\%20Eco-efficient.pdf.

Pinxterhuis, I.; Coltman, T.; Edwards, P.; Parker, L. 2017. Achieving the required $\mathrm{N}$ leaching reductions on dairy farms in the Selwyn Area, Canterbury - A real-life example. pp. 68-79. In: Proceedings South Island Dairy Event 2017. Accessed 15th August 2018. https://side.org.nz/wp-content/uploads/2017/06/2.3Achieving-the-required-N-leaching-reductions-InaPinxterhius.pdf.

Pinxterhuis, I.; Kuhn-Sherlock, B.; Dennis, S. 2015b. Matrix of Good Management - Estimating nutrient loss of Canterbury dairy farm systems operating at Good Management Practice. DairyNZ report, 191 pp. Accessed 4th August 2018. https:// api.ecan.govt.nz/TrimPublicAPI/documents/ download/2480266.

Schröder, J.J.; Neeteson, J.J. 2008. Nutrient management regulations in the Netherlands. Geoderma 144: 418425 .

Waghorn, G.C.; Collier, K.; Bryant, M.; Dalley, D. 2018. Feeding fodder beet (Beta vulgaris L.) with either barley straw or pasture silage to non-lactating dairy cows. New Zealand Veterinary Journal 66; DOI: 10.1080/00480169.2018.1465484.

Watkins, N.; Selbie, D. 2015. Technical Description of OVERSEER for Regional Councils, Report prepared for Bay of Plenty Regional Council, RE500/2015/084. Accessed: 9th May 2018. https://www.overseer.org. nz/technical-description-of-overseer.

Whitehead, D.C. 1995. Grassland Nitrogen. CAB International, Wallingford, Oxford, UK. 397 pp.

Woods, R.R. 2017. The effect of alternative forage species and gibberellic acid on nitrate leaching. $\mathrm{PhD}$ thesis. Lincoln University. Accessed: 4th August 2018. https://researcharchive.lincoln.ac.nz/ handle/10182/8271. 